\title{
Róża Różańska
}

\section{„Angels and Men' assisted by this Art, May Sing together, though they Dwell apart"1 - angielskie antologie świeckiej i religijnej muzyki wokalnej z drugiej połowy XVII wieku w kolekcji Biblioteki Jagiellońskiej}

Przechowywana przez Bibliotekę Jagiellońską kolekcja muzykaliów z byłej Pruskiej Biblioteki Państwowej w Berlinie, powszechnie znana pod nazwą Berlinka, skrywa siedemnaście angielskich antologii solowej twórczości pieśniowej opublikowanych między 1659 a 1700 rokiem. Wspomniane muzykalia łączy osoba Johna Playforda, najsłynniejszego londyńskiego wydawcy Xviı stulecia, autora niezwykle cenionych antologii, a także najpopularniejszego podręcznika do nauki tańca w nowożytnej Europie, oraz jego syna Henry’ego. Muzykolodzy od czasu przejęcia kolekcji przez krakowską Wszechnicę prowadzą intensywne badania tych zasobów; brytyjskie druki wciąż jednak nie doczekały się omówienia, zaś postaci ich wydawców pozostają zupełnie nieznane w polskiej literaturze muzykologicznej. Także wśród anglojęzycznych opracowań brakuje osobnych studiów poświęconych

1 Motto na stronie tytułowej drugiej księgi antologii Harmonia Sacra or Divine Hymns and Dialogues. With a Thorow-Bass for the Theorbo-Lute, Bass-Viol. Harpsichord, or Organ, wyd. H. Playford, Londyn 1693; tłum. autorki: „Aniołowie wraz z ludźmi wspierani tą sztuką mogą śpiewać razem, choć rezydują oddzielnie”. 
poszczególnym antologiom, jak również zapomnianym kompozytorom, których utwory wypełniają te barokowe publikacje.

Celem niniejszego tekstu jest zaprezentowanie polskiemu czytelnikowi siedemnastu angielskich starodruków z drugiej połowy xVII stulecia przechowywanych w Bibliotece Jagiellońskiej. Jest to pierwsza próba syntetycznego ujęcia tego tematu. Początkowa część pracy omawia losy głównych przedstawicieli rodziny Playfordów oraz prezentuje stan badań nad działalnością londyńskich wydawców. Część druga zawiera spis antologii będących w posiadaniu Biblioteki Uniwersytetu Jagiellońskiego, wskazując na najbardziej popularne kolekcje. Ostatnia część stanowi omówienie treści prezentowanych zbiorów - zawiera krótką charakterystykę gatunku angielskiej pieśni (ayre), porusza temat popularności kolekcji małych form wokalnych w Anglii xvıI stulecia, a ponadto przybliża postaci kompozytorów, których utwory znajdują się w antologiach.

\section{Działalność Johna i Henry'ego Playfordów na tle muzycznej panoramy Londynu doby Stuartów}

Żyjący w latach 1623-1686 John Playford działał jako handlarz nutami i książkami o tematyce muzycznej, wydawca traktatów teoretycznych, szkół gry na instrumentach oraz psałterzy, a także jako okazjonalny kompozytor. W trzeciej ćwierci XVIII stulecia na krótko udało mu się zmonopolizować muzyczny rynek wydawniczy w Wielkiej Brytanii ${ }^{2}$. Pomimo iż przedsiębiorca działalność rozpoczął w czasach dyktatorskiej władzy Olivera Cromwella, karierę rozwinął dopiero za rządów Karola II Stuarta, a zatem po 1660 roku.

Playford od 1647 roku prowadził swój sklep w pobliżu Temple Church, dawnego kościoła Templariuszy w londyńskiej dzielnicy Holborn. Był związany z tą świątynią również osobiście, gdyż od roku 1653 pełnił w niej funkcję kancelisty. Gros informacji dotyczących wydawcy zawdzięczamy jego zawodowej aktywności, był on bowiem członkiem gildii wydawniczej The Stationers' Company ${ }^{3}$. Organizacja

2 Sylwetki J. Playforda oraz H. Playforda zostały opracowane na postawie: M. Dean-Smith, N. Temperley, Playford, [w:] The New Grove of Music and Musicians, red. D. Root i in., [online] http://www.oxfordmusiconline.com/public/ book/omo_gmo [dostęp: 8.04.2016].

3 N. Temperley, John Playford and the Stationers' Company, „Music \& Letters” 1973, t. 54, nr 2, s. 203-212. 
owa powstała w XV stuleciu, a w 1557 roku otrzymała królewski patent zapewniający jej monopol na angielskim rynku wydawniczym ${ }^{4}$. Przywilej wygasł w roku 1709, dopiero za panowania Anny Stuart, wraz z wejściem w życie ustawy parlamentu angielskiego ${ }^{5}$ znanej jako Copyright Act bądź też Statut Królowej Anny .

John Playford przystąpił do związku w 1650 roku, bowiem wyłącznie członkostwo w The Stationers' Company uprawniało do publikacji książek, zaś przedsiębiorca w owym czasie przygotowywał wydanie The English Dancing Master. Obecnie wydawca jest pamiętany przede wszystkim jako autor tegoż dwudziestoczterokrotnie wznawianego podręcznika do nauki tańca. Kolekcja stu pięciu utworów tanecznych wraz z podstawą teoretyczną została opublikowana w 1651 roku, a zatem w czasach purytańskiego reżimu Cromwella, zaś niesłabnącą popularnością cieszyła się przez niemal sto pięćdziesiąt lat ${ }^{7}$. Znacznym sukcesem komercyjnym okazał się również podręcznik A Breefe Introduction to the Skill of Musick, wydany po raz pierwszy w 1654 roku, wielokrotnie cytowany w innych tekstach teoretycznych i funkcjonujący w obiegu przez ponad sto lat. Natomiast opracowania psalmów autorstwa Playforda zyskały renomę tuż po jego śmierci, pozostając w użyciu w Szkocji i Stanach Zjednoczonych do XVIII wieku.

W latach osiemdziesiątych XVII stulecia John Playford uzyskał największe profity za wierność okazaną Stuartom. Z rozkazu Karola II został wyznaczony do pośredniczenia w kontaktach z dworem, zaś w 1681 roku desygnowany jako udziałowiec w akcjach monopolu The Stationers' Company, z czego czerpał znaczne korzyści finansowe. W 1684 roku odszedł z zawodu, a dwa lata później zmarł. Przedsiębiorstwo przejął jego syn, Henry Playford (1657-1709), jednakże z powodu

4 C. Blagden, The Stationers' Company. A History, 1403-1959, Stanford University 1977 , s. 19-22, 34-46.

5 Określenia „parlament brytyjski” zaczęto używać dopiero w 1707 roku po zawarciu unii łączącej parlament angielski z parlamentem szkockim, zob. Parliament, [w:] Encyclopedia Britannica, [online] http://global.britannica.com/ topic/Parliament\#toc215007 [dostęp: 10.05.2016].

6 Global copyright. Three hundred years since the Statute of Anne, from 1709 to cyberspace, red. L. Bentlyi in., Cheltenham 2010.

7 R.M. Keller, The Dancing Master, 1651-1728. An Illustrated Compendium, [online] http://www.izaak.unh.edu/nhltmd/indexes/dancingmaster/ [dostęp: 30.03.2016]. 
niechęci do wprowadzenia nowoczesnych technik grawerunku oraz raptownego wzrostu konkurencji nie udało mu się utrwalić sukcesów swego ojca. Pomimo tego młodszego Playforda określa się jako najbardziej znanego londyńskiego wydawcę muzykaliów lat osiemdziesiątych i dziewięćdziesiątych XVII stulecia. Dokonał on licznych reedycji serii zapoczątkowanych przez ojca. Wydawca zmarł bezpotomnie, przekazawszy swoje dziedzictwo w ręce Johna i Benjamina Sprintów oraz Williama Pearsona.

Współczesne zainteresowanie muzykologów osobą siedemnastowiecznego przedsiębiorcy zapoczątkowały dwa opracowania przypominające o znaczeniu Johna Playforda dla brytyjskiego rynku publikacji muzycznych, napisane w drugiej dekadzie $\mathrm{xx}$ wieku. $\mathrm{Od}$ tamtej pory ukazało się kilka pojedynczych artykułów traktujących głównie o działalności wydawniczej Playforda, szczególnie wpisanej w panoramę epoki ${ }^{9}$, zaś w znacznie mniejszym stopniu o jego preferencjach odnośnie do współpracy z poszczególnymi artystami czy też osiągnięciach na polu kompozycji ${ }^{10}$. Jedyny artykuł skupiający się na treści i bogactwie publikacji pochodzi z $1926 \mathrm{roku}^{11}$ i prócz biograficznego hasła $\mathrm{w}$ największej anglojęzycznej encyklopedii ${ }^{12}$ nie znajdziemy innego kompleksowego ujęcia charakterystyki tego

8 F. Kidston, The Petition of Mrs Eleanor Playford, „The Library” 1916, t. VII, s. 346; tenże, John Playford, and 17th-Century Music Publishing, „The Musical Quarterly" 1918, t. 4, nr 4, s. 516-534.

9 W kolejności chronologicznej: W.C. Smith, Playford: some hitherto unnoticed catalogues of early Music, „The Musical Times” 1926, t.67, nr 1001, s. 636-639; M. Dean-Smith, English Tunes Common to Playford's Dancing Master, the Keyboard Books and Traditional Songs and Dances. Preceded by Some New Findings Concerning the Life and Career of John Playford, „Proceedings of the Royal Musical Association" 1952, t. 79; N. Temperley, John Playford and the Stationers' Company, „Music \& Letters” 1972, t. 54, nr 2, s. 203-212; P. Lindenbaum, John Playford: Music and politics in the interregnum, „Huntington Library Quarterly" 2001, t.64, nr 1/2, s. 125-138; J. Barnard, London Publishing, 1640-1660. Crisis, Continuity, and Innovation, „Book History” 2001,t. 4, $\mathrm{nr}$ 1, s. 1-16; ponadto dwie dysertacje doktorskie: M.M. Curti, John Playford's "Apollo's Banquet" 1670 , The State University of New Jersey 1977; P.A. Munstedt, John Playford, music publisher: a bibliographical catalogue, University of Kentucky 1983.

10 N. Temperley, John Playford and the metrical psalms, „Journal of the American Musicological Society" 1972, t. 25, nr 3, s. 331-378.

11 W.C. Smith, dz. cyt.

12 M. Dean-Smith, N. Temperley, dz. cyt. 
dorobku. Również wątek związany z technicznymi aspektami warsztatu pracy sławnego wydawcy jest marginalizowany. Taki stan rzeczy wynika poniekąd ze specyfiki zachowanych archiwaliów. Tylko nieliczne źródła dokumentują aktywność zawodową Playforda, a dodatkowo działania badaczy znacznie ogranicza niemal całkowity brak jakichkolwiek danych pozwalających poznać jego charakter czy życie prywatne ${ }^{13}$. Jak już wspomniano, wydawca jest obecnie znany głównie jako autor The English Dancing Master, co wynika po części $\mathrm{z}$ historycznego znaczenia samej publikacji, lecz również ze wzrostu zainteresowania odtwarzaniem dawnych tańców ${ }^{14}$. Najnowsza pozycja, podejmująca temat roli Playforda w kształtowaniu życia muzycznego w Anglii w czasach restauracji Stuartów, powstała w $2010 \mathrm{roku}^{15}$.

Biografia młodszego z Playfordów bywa zwykle dołączana do opracowań dotyczących życia i działalności jego ojca. Henry Playford nie doczekał się nawet osobnego hasła w encyklopedii The New Grove Dictionary of Music and Musicians. Jego dorobek stanowi przedmiot dysertacji doktorskiej na nowozelandzkim Uniwersytecie Wiktorii ${ }^{16}$. Osiągnięcia wydawcy są głównie sprowadzane do wydawania reedycji druków jego ojca oraz kontynuowania współpracy z niezwykle cenionym ówcześnie Henrym Purcellem ${ }^{17}$.

Dwie antologie wchodzące w skład kolekcji tzw. Berlinki opublikował John Carr we współpracy z Samuelem Smithem. Niewiele wiadomo o życiu i działalności Carra. Aktywny w latach 1672-1695 wydawca posiadał sklep w okolicy Middle Temple Gate w Londynie, a zatem w pobliżu miejsca pracy Johna Playforda. Obaj przedsiębiorcy opublikowali wspólnie kilka druków tuż przed wycofaniem się Playforda z zawodu ${ }^{18}$. Losy Samuela Smitha pozostają nieznane.

13 Konstatację ową przedstawił N. Temperley, John Playford and the Stationers'..., dz. cyt., s. 203.

14 K.Whitlock, John Playford's the English Dancing Master 1650/51 as Cultural Politics, „Folk Music Journal” 1999, s. 548-578.

15 R. Herissone, Playford, Purcell, and the Functions of Music Publishing in Restoration England, „Journal of the American Musicological Society” 2010, t. 63, nr 2, s. 243-29o. D.R. Harvey, Henry Playford: A Bibliographical Study, New Zeland School of Music 1985, [online] http://researcharchive.vuw.ac.nz/handle/10063/309 [dostęp: 28.03.2016].

17 M. Dean-Smith, N. Temperley, dz. cyt.

18 M. Miller., Carr John, [w:] The New Grove of Music and Musicians, dz. cyt. 


\section{Angielskie antologie wokalne w kolekcji Biblioteki Jagiellońskiej}

W Bibliotece Jagiellońskiej znajduje się siedemnaście angielskich zbiorów pieśni i arii, z czego piętnaście jest sygnowanych nazwiskiem Playford (w tym wyłącznie druki Mus. ant. pract. 970 [1] oraz Mus. ant. pract. P 982 ukazały się pod nadzorem Johna Playforda, zaś pozostałe pochodzą z czasów działalności jego syna). Jedyne publikacje niezwiązane z rodziną Playfordów, dwa tomy Comes Amoris pochodzące z lat 1687-1688 (Mus. ant. pract. C 835 [1] oraz [2]), a także niezidentyfikowana dotychczas, niekompletnie zachowana publikacja Mus. ant. pract. M 400, zostały wydane przez Johna Carra i Samuela Scotta [4]. Wszystkie omawiane starodruki pochodzą z lat 1659-1700. W obrębie charakteryzowanej grupy dominują kompozycje świeckie, utwory religijne wypełniają wyłącznie druk pt. Harmonia Sacra z 1693 roku (Mus. ant. pract. P 995 [1]) oraz jego suplement Two Divine Hymns Z 1700 roku (Mus. ant. pract. P 995 [2]). Tabela na stronach 131-133 zbiera dane na temat wszystkich wymienionych tu antologii; zostały one przedstawione w kolejności chronologicznej.

Warto zwrócić uwagę, iż wśród druków zachowanych w kolekcji byłej Pruskiej Biblioteki Państwowej w Berlinie znajdują się najbardziej znane serie antologii Henry'ego Playforda ${ }^{19}$ - trzeci i czwarty tom The Theatre of Music, pierwszy i drugi tom The Banquet of Music oraz wszystkie cztery tomy Deliciae Musicae.

\section{Zawartość zbiorów}

Antologie znajdujące się w posiadaniu Biblioteki Jagiellońskiej zawierają wybór pieśni przeznaczonych na głos solowy z towarzyszeniem instrumentalnym. Utwory owe reprezentują gatunek pieśni angielskiej. Mianem ayre określano w językach francuskim i angielskim formę świeckiej pieśni $z$ towarzyszeniem instrumentalnym, skomponowaną jako przeważnie samodzielny utwór, zwykle wydawaną w zbiorach ${ }^{20}$. Forma owa wywodziła się z monodii akompaniowanej. Synonimicznymi terminami dla tego typu kompozycji w języku angielskim były:

19 Por. M. Dean-Smith, N. Temperley, dz. cyt.

20 Paragraf został opracowany na podstawie: N. Fortune, D. Greer, Ch. Dill, Air,

[w:] The New Grove of Music and Musicians, dz. cyt. 
melody, tune lub też song. Popularność pieśni z towarzyszeniem lutni wzrosła pod koniec panowania Elżbiety II, po 1597 roku, głównie za sprawą publikacji zbioru Johna Dowlanda pt. The First Booke of Songes or Ayres. Wszystkie arie zawarte w omawianych drukach zostały napisane do tekstu literackiego w języku angielskim. Pojedyncze publikacje składają się także z duetów, określanych ówcześnie mianem dialogów ${ }^{21}$. Wypełniają one druki: najstarszy zbiór wydany w 1659 roku Mus. ant. pract. 970 [1], obie antologie Harmonia Sacra i ich suplement (Mus. ant. pract. P 985 [1] i Mus. ant. pract. P 995 [1] oraz [2]).

Około połowy XVII stulecia moda na grę na lutni powoli ustąpiła zainteresowaniu instrumentami klawiszowymi. Odzwierciedlenie tej tendencji przełożyło się na zmianę obsady. Zbiory wydane po 1650 roku ujawniają predylekcję do wspierania głosu wokalnego akompaniamentem typu continuo, w którego skład zwykle wchodził klawesyn, viola basowa i/lub teorba. Taki skład instrumentalny został przewidziany $\mathrm{w}$ większości analizowanych publikacji, nie odnajdziemy go jedynie w najwcześniejszym ze zbiorów, wydanym przez Johna Playforda w 1659 roku (Mus. ant. pract. 970 [1]); w czterech antologiach Deliciae Musicae z lat 1695-1696 (Mus. ant. pract. P 995 [3], [4], [5] oraz [6]), a poza tym w niezidentyfikowanej publikacji z 1700 roku (Mus. ant. pract. 400 [4]) do pozostałych instrumentów dochodzi flet. Wedle opisu zawartego na kartach tytułowych charakteryzowanych druków autorzy proponują wymienne użycie organów lub klawesynu, co też należy do typowych ówcześnie rozwiązań. Zbiory muzyki religijnej zawierają protestanckie hymny w języku angielskim ${ }^{22}$, również zakładające akompaniament klawesynu oraz teorby i/lub violi basowej. Antologie arii cieszyły się w Anglii znaczną popularnością w epoce elżbietańskiej, jak i w czasach panowania Stuartów. Niewielki poziom trudności technicznej umożliwiał wykonanie utworów amatorom, zaś kameralny akompaniament doskonale sprawdzał się podczas muzykowania $\mathrm{w}$ domowym zaciszu ${ }^{23}$.

Omawiane druki wypełniają utwory mało znanych dziś twórców, których nazwiska częstokroć przetrwały jedynie w owych publikacjach;

21 I. Spink, English seventeenth-century dialogues, „Music \& Letters” 1957, t. 38, nr 2, s. 155-163.

22 Por. H. Eskew, Hymn, § IV: Protestant, [w:] The New Grove of Music and Musicians, dz. cyt.

23 Zob. M.F. Bukofzer, Music in the Baroque Era. From Monteverdi to Bach, New York 1947, s. 180-218. 
jednakże dla ówczesnych konsumentów kultury stworzone przez nich kompozycje stanowiły atrakcyjną ofertę. W sumie w zbiorach widnieją sześćdziesiąt trzy nazwiska, a pozostałe dziesięć kompozycji jest oznaczonych jako anonimowe. Liczba utworów w zbiorze waha się od stu trzynastu w najwcześniejszym $\mathrm{z}$ druków do sześciu w czwartej księdze Deliciae Musicae. Przeważnie księgi zawierają od kilkunastu do trzydziestu kompozycji. Najstarszy zbiór pochodzący z 1659 roku obejmuje kompozycje zapomnianych mistrzów lutni (m.in. Williama Caesara), wirtuozów tegoż instrumentu związanych z dworem Karola I (m.in. Roberta Johnsona, muzyka kapeli przyszłego Karola $\mathrm{II}^{24}$ ), a także dwa utwory samego Johna Playforda. Nazwiska z omawianego druku nie powtarzają się w późniejszych antologiach, co najprawdopodobniej wynika z faktu, iż pierwszą publikację dzieli od kolejnej niemal ćwierć wieku. Większość zbiorów składa się z kompozycji muzyków zatrudnianych przez Karola II oraz Wilhelma III Orańskiego i królową Mary. Biorąc pod uwagę częstotliwość statystyczną pojawiania się poszczególnych nazwisk kompozytorów, w konkretnych antologiach odnajdziemy utwory m.in.: - w sześciu zbiorach - autorstwa Samuela Akeroyde (aktywnego w latach 1684-1706), wiolisty wymienianego na liście muzyków Wilhelma III Orańskiego ${ }^{25}$;

- w pięciu zbiorach - Jamesa Harta (1647-1718), basa i kompozytora, od 1670 roku członka kapeli Kaplicy Królewskiej (the Royal Chapel) ${ }^{26}$; - w pięciu zbiorach - Daniela Purcella (ok. 1664-1717), muzyka kapeli Kaplicy Królewskiej, autora kompozycji dedykowanych królowej Annie Stuart i innym członkom rodziny królewskiej, najprawdopodobniej kuzyna lub brata słynnego Henry'ego Purcella27;

- w pięciu zbiorach - Mosesa Snowa (1661-1702), śpiewaka, organisty i kompozytora, muzyka kapeli królewskiej (king's 'privatemusick'), a od 1689 roku kapeli Kaplicy Królewskiej Wilhelma III Orańskiego ${ }^{28}$; - w czterech zbiorach - Raphaela Courteville'a (aktywnego w latach 1675-1735), organisty i kompozytora należącego do zespołu muzyków Kaplicy Królewskiej29;

24 I. Spink, Johnson Robert,[w:] The New Grove of Music and Musicians, dz. cyt.

25 Tenże, Akeroyde Samuel, [w:] The New Grove of Music and Musicians, dz. cyt.

26 Tenże, Hart James, [w:] The New Grove of Music and Musicians, dz. cyt.

27 M. Humphreys, Daniel Purcell, [online] http://www.danielpurcell.bemused. org.uk/ [dostęp: 5.03.2016].

28 I. Spink, Snow Moses, [w:] The New Grove of Music and Musicians, dz. cyt.

29 Tenże, Courteville Raphael, [w:] The New Grove of Music and Musicians, dz. cyt. 
- w czterech zbiorach - Alexandra Damascene (zm. 1719), kontratenora i kompozytora, członka zespołu wokalistów Karola II, zaś później jednego z nadwornych kompozytorów Wilhelma III i królowej Mary ${ }^{30}$; - w czterech zbiorach - Roberta Kinga (ok. 1660-1728), skrzypka, flecisty, klawesynisty i kompozytora zatrudnionego m.in. w królewskim teatrze za panowania Karola $\mathrm{II}^{31}$;

- w czterech zbiorach - Williama Turnera (1651-1740), kompozytora i śpiewaka związanego z kapelą Kaplicy Królewskiej za czasów Karola II, zaś później z zespołem prywatnych komnat tego monarchy ${ }^{32}$; - w trzech zbiorach - Jeremiaha Clarke’a (przed 1674-1707), chórzysty kapeli Kaplicy Królewskiej pełniącego ową funkcję w czasach Jakuba II Stuarta ${ }^{33}$;

- w trzech zbiorach - Johna Ecclesa (1668-1735), komponującego głównie na potrzeby teatru i opery ${ }^{34}$;

- w trzech zbiorach - Thomasa Farmera (zm. 1688), skrzypka i kompozytora, instrumentalisty Jakuba II Stuarta wykonującego muzykę komnatową oraz występującego z kapelą Kaplicy Królewskiej35;

- w trzech zbiorach - Alfonsa Marsha (zm. 1692), lutnisty, tenora i kompozytora, solisty kapeli Kaplicy Królewskiej w czasach Jakuba II Stuarta oraz Wilhelma III Orańskiego ${ }^{36}$;

- w dwóch zbiorach - Johna Readinga (ok. 1645-1692), organisty i kompozytora związanego przez większość aktywności zawodowej z Katedrą w Winchesterze ${ }^{37}$.

Ponadto w pojedynczych zbiorach pojawiają się nazwiska m.in.:

- Humphreya Pelhama (1647-1674), wysłanego na studia do Paryża przez króla Karola II Stuarta, później koryfeusza chóru chłopięcego kapeli Kaplicy Królewskiej38;

30 Tenże, Damascene Alexander, [w:] The New Grove of Music and Musicians, dz. cyt.

31 P. Holman, King Robert, [w:] The New Grove of Music and Musicians, dz. cyt.

32 D. Franklin, Turner William, [w:] The New Grove of Music and Musicians, dz. cyt.

33 W. Shaw, Ch. Powell, H.D. Johnstone, Clarke Jeremiah, [w:] The New Grove of Music and Musicians, dz. cyt.

34 M. Laurie, S. Lincoln, John Eccles, [w:] The New Grove of Music and Musicians, dz. cyt.

35 P. Holman, Farmer Thomas, [w:] The New Grove of Music and Musicians, dz. cyt.

36 I. Spink, Marsh Alfonso, [w:] The New Grove of Music and Musicians, dz. cyt.

37 S. Jeans, John Reading, [w:] The New Grove of Music and Musicians, dz. cyt.

38 B. Wood, Humphrey Pelham, [w:] The New Grove of Music and Musicians, dz. cyt. 
- Williama Crofta (1678-1727), kompozytora i organisty zatrudnionego w kapeli Kaplicy Królewskiej, koryfeusza chóru chłopięcego kapeli Kaplicy Królewskiej, autora muzyki na uroczystości żałobne na cześć królowej Anny Stuart oraz na koronację Jerzego I Hanowerskiego ${ }^{39}$.

Do największych muzycznych osobistości przewijających się na kartach badanych antologii należą: Henry Purcell (1659-1695), organista kapeli Kaplicy Królewskiej, którego utwory są obecne w dwunastu drukach, a zatem niemal we wszystkich antologiach; doktor John Blow (1643-1708), organista Katedry Westminsterskiej, od 1699 roku pierwszy mianowany kompozytor kapeli Kaplicy Królewskiej Wilhelma III Orańskiego ${ }^{40}$, którego utwory zostały wydane $\mathrm{w}$ dziesięciu $\mathrm{z}$ charakteryzowanych zbiorów; Matthew Locke (ok. 1621-1677), kompozytor i organista uznany za wiodącego twórcę na Wyspach do czasu upadku Republiki Angielskiej, po 1660 roku piszący dla kapeli Kaplicy Królewskiej ${ }^{41}$, którego dzieła znajdują się w dwóch zbiorach. Owi artyści również byli silnie związani z kręgiem dworskim i określani za życia jako wybitni. Jedynym świadectwem recepcji zagranicznego repertuaru w omawianych drukach jest pojawiające się w jednej z publikacji nazwisko włoskiego kompozytora Giacoma Carissimiego (1605-1674), uchodzącego, obok kilku innych, za najważniejszego twórcę XVII stulecia i przedstawiciela szkoły rzymskiej; jego artystyczne dokonania niewątpliwie inspirowały angielskich twórców ${ }^{42}$.

Powyższe wyliczenie pokazuje silny związek pomiędzy autorami utworów w antologiach a kręgami dworskimi. Tym samym zawartość zbiorów odzwierciedlała muzyczne mody i tendencje uprzywilejowanych warstw społecznych. Można zatem wnioskować, iż zakup druków muzycznych pozwalał przedstawicielom drobnej szlachty i mieszczaństwa wkroczyć w świat zarezerwowany wyłącznie dla elity ${ }^{43}$.

39 W. Shaw, G. Beeks, Croft William, [w:] The New Grove of Music and Musicians, dz. cyt.

40 B. Wood, Blow John, [w:] The New Grove of Music and Musicians, dz. cyt.

41 P. Holman, Locke Matthew, [w:] The New Grove of Music and Musicians, dz. cyt.

42 A.V. Jones, Carissimi Giacomo, [w:] The New Grove of Music and Musicians, dz. cyt.

43 Więcej o migracji własności intelektualnej pomiędzy dworem angielskim a pozostałymi warstwami społeczeństwa: R. Herissone, Musical Creativity in Restoration England, Cambridge University 2013; M. Jenkinson, Culture and Politics at the Court of Charles II, 1660-1685, Suffolk 2010. 
Teksty literackie kompozycji zawartych $\mathrm{w}$ antologiach pozostają w większości niezidentyfikowane. Jedynie w niektórych ariach $\mathrm{z}$ czwartej księgi antologii The Theatre of Music $\mathrm{z} 1685$ roku stwierdzono autorstwo sławnego libertyna i cenionego w epoce poety - Johna Wilmota, 2. hrabiego Rochestera ${ }^{44}$.

Utwory z antologii Playfordów i pozostałych omówionych zbiorów stosunkowo rzadko pojawiają się w koncertowym repertuarze. Wynika to prawdopodobnie ze specyficznych utrudnień w odczytaniu tekstu nutowego. Pomimo iż większość owych publikacji można zdobyć bezpłatnie w Internecie ${ }^{45}$ dzięki coraz powszechniejszej inicjatywie digitalizacji zasobów bibliotek, takie czynniki jak: zapis utworów w stylu przypominającym białą notację menzuralną, brak „ciągłości pięciolinii" wynikający z użycia pojedynczych czcionek drukarskich, gramatura papieru, obecność licznych skaz czy przebarwień, krój czcionek literowych, a wreszcie specyfika odcyfrowania partii continuo mogą powodować, iż wykonanie pozostanie zarezerwowane dla muzyków praktykujących w nurcie wykonawstwa historycznego. Jedną z nielicznych reedycji scharakteryzowanych antologii stanowi wydana w 2011 roku publikacja amerykańskiej oficyny ЕЕво Editions, będąca współczesnym opracowaniem czwartej księgi The Theatre of Music $^{46}$. Zbiór wchodzi w skład serii reprodukcji historycznych wydań nutowych, obejmującej obecnie setki pozycji.

Prezentowany artykuł jest wstępnym rozpoznaniem zawartości siedemnastowiecznych zbiorów angielskich z kolekcji Uniwersytetu Jagiellońskiego. Biografie wydawców oraz krótkie charakterystyki życiorysów najważniejszych kompozytorów pomogły w nakreśleniu historycznych okoliczności powstania publikacji. Wskazane zostały

44 That Second Bottle. Essays on the Earl of Rochester, red. N. Fisher, Manchester University 2000, s. 74. Swoista komercjalizacja losów Earla Rochestera nastąpiła w 2004 roku wraz z premierą filmu pod tytułem The Libertine w reżyserii Laurence’a Dunmore'a, w którym w rolę tytułową wcielił się Johnny Depp. Jeden z największych serwisów zapewniających dostęp do archiwalnych publikacji muzycznych, Petrucci Music Library, znany pod akronimem IMSLP, zawiera m.in. pierwszą edycję serii The Theatre of Music http://imslp.org/wiki/ The_Theater_of_Music_(Playford,_John) oraz serię Harmoniae Sacrae http:// imslp.org/wiki/Harmonia_Sacra_(Playford,_Henry), a ponadto szóstą księgę The Banquet of Music http://imslp.org/wiki/The_Banquet_of_Musick_(Playford,_Henry) [dostęp: 17.03.2016].

46 Numer ISBN 9781240951604, [online] http://eebo.chadwyck.com/about/about. htm [dostęp: 1.03.2016]. 
związki repertuaru zawartego $\mathrm{w}$ drukach z życiem muzycznym angielskiego dworu królewskiego, a ponadto podjęta została próba określenia odbiorców publikacji. Rozmiary tegoż komunikatu naukowego pozwoliły na dokonanie ogólnej charakterystyki grupy siedemnastu starodruków. Autorka żywi nadzieję, iż niniejsze opracowanie przyczyni się do wzrostu zainteresowania angielskimi antologiami przechowywanymi w Bibliotece Jagiellońskiej oraz że będzie ono stanowiło punkt wyjścia dla dalszych badań.

\begin{tabular}{|c|c|c|}
\hline Sygnatura & Karta tytułowa & Kompozytorzy \\
\hline $\begin{array}{l}\text { Mus. ant. } \\
\text { pract. } 970 \\
\quad[1]\end{array}$ & $\begin{array}{c}\text { SELECT | AYRES | AND | DIALOGUES | For One, } \\
\text { Two, and Three Voices: | TO THE | THEORBO- } \\
\text { LUTE or BASSE-VIOL | Composed by John } \\
\text { Wilson | Charles Colman | Doctors of Musick. | } \\
\text { Henry Lawes | William Lawes | Nicholas Laneare } \\
\text { |William Webb | Gentlemen and Servents to } \\
\text { his late | Majesty in his Publick and Private | } \\
\text { Musick. | And other Excellent Masters of Musick } \\
\text { | LONDON | Printed by W. Godbid for John } \\
\text { Playford, } 1659 .\end{array}$ & $\begin{array}{l}\text { Tho. Brewer, William Caesar, } \\
\text { Charles Colman, Edward } \\
\text { Colman, Lady Deering, John } \\
\text { Goodsgroome, Simon Ives, } \\
\text { Jankins, Robert Johnson, } \\
\text { Nich. Laneere, Henry } \\
\text { Lawes, William Lawes, } \\
\text { John Playford, Jeremy Savil, } \\
\text { William Tompkins, Warner, } \\
\text { William Webb, John Wilson, } \\
\text { Anonim }\end{array}$ \\
\hline $\begin{array}{l}\text { Mus. ant. } \\
\text { pract. P } \\
\quad 982\end{array}$ & $\begin{array}{c}\text { /brak oryginalnej strony tytułowej/ John } \\
\text { Playford (jun.): | Choic Ayres and Songs | } \\
\text { The 4th book | London 1683. - London, John } \\
\text { Playford, 1683. }\end{array}$ & $\begin{array}{l}\text { John Blow, Capt. Pack, } \\
\text { Henry Purcell, Anonim }\end{array}$ \\
\hline $\begin{array}{l}\text { Mus. ant. } \\
\text { pract. P } \\
985[2]\end{array}$ & $\begin{array}{l}\text { THE | Theater of MUSIC | OR, A | Choice } \\
\text { COLLECTION of the newest and best Songs | } \\
\text { Sung at the COURT, and Public THEATERS, } \\
\text { | The Words composed by the most ingenious } \\
\text { Wits of the Age, and set to | MUSIC by the } \\
\text { greatest Masters in that Science. | WITH | A } \\
\text { THEORBO-BASS to each Song for the Theorbo, } \\
\text { or Bass-Viol. | ALSO | Symphonics and Ritornels } \\
\text { in } 3 \text { Parts to several of them for Violins and } \\
\text { Flutes. | Printed by J. Playford, for Henry } \\
\text { Playford and R.C. and are to be sold near the | } \\
\text { Temple Church, and at the Middle-Temple Gate, } \\
\text { 1685. - London, J. Playford for Henry Playford, } \\
\text { 1685. }\end{array}$ & $\begin{array}{c}\text { S. Akeroyde, Baptist, J. Blow, } \\
\text { A. Damascene, T. Farmer, L. } \\
\text { Grabu, W. Gregory, J. Hart, } \\
\text { R. King, J. Lenton, Pack, H. } \\
\text { Purcell, P. Reggio, J. Rofey, } \\
\text { Snow, Ch. Taylor, W. Turner, } \\
\text { Anonim }\end{array}$ \\
\hline
\end{tabular}


Mus. ant.

pract. $\mathrm{P}$

$985[5]$

\begin{tabular}{|c|c|}
\hline 985 [5] & [London], s.n. [J.Playford], s.d. [1686]. \\
\hline & COMES AMORIS; | OR THE | Companion \\
of LOVE. | Being a Choice COLLECTION | \\
Of the Newest SONGS now in Use. | WITH \\
| A THOROW BASS each SONG for the
\end{tabular}

Mus. ant.

pract. C

$835[1]$
John Blow, Richard Brown, John Lenton, Henry Purcell, Anonim
FIRST BOOK. | LONDON. Printed by Nat.

Thompson for John Carr and Sam. Scott, and are to be sold by John $\mid$ Carr at his Shop at the Middle Temple Gate, Anno Domini, 1687. London, Nathaniel Thompson for John Carr \& Samuel Scott, 1687.
Mus. ant.

pract. $\mathrm{P}$

985 [3]

Mus. ant.

pract. $\mathrm{P}$

$985[1]$

Mus. ant.

pract. $\mathrm{P}$

$985[6]$
THE | Theater of MUSIC: | OR, $A$ | Choice COLLECTION [...] The FOURTH and LAST BOOK. | LONDON. | Printed by B. Motte for Henry Playford, 1687.
Sam. Aykroyde, R.

Courteville, A. Damascene, Tho. Farmar, Charles Green, G. Hart, James Hart, Robert King, Henry Purcell, Thomas Shadwell, Will. Turner, Anonim

S. Akeroyde, W. Aylworth, Baptist, J. Blow, Courteville, A. Damascene, Th. Farmer, Gore, George Hart, James Hart, Th. Hawney, J. Jackson, R. King, M. Locke, A. Marsh, H. Purcell, J Reading, J. Roffey, Snow, W. Turner

Harmonia Sacra; | OR | DIVINE HYMNS | AND | DIALOGUES: | With | A THOROW-BASS for the Theorbo-Lute, |Bass-Viol. Harpsichord, or Organ. | Composed by the Best Masters of the Last and Present Age. | The WORDS by several Learned and Pious Persons | [...] In the SAVOY: | Printed by Edward Johnes, for Henry Playford, at his Shop near the Temple Church, | MDCLXXXVIII. - London, Edward Johnes for Henry Playford, 1688.

The | Banquet of MUSICK; | OR, A Collection of the newest and best SONGS sung at the Court, and at Publick Theatres. | WITH | A THOROW-BASS for the Theorbo-Lute, | BassViol, Harpsichord, or Organ. | Composed by several of the Best Masters. The WORDS by the Ingenious Wits of this Age. THE FIRST BOOK. | Licensed, | Nov. 19.1687. Rob. Midgley. In the SAVOY: | Printed by E. Jones, for Henry Playford, at his Shop near the Temple Church. 1688. London, E. Jones for Henry Playford, 1688.

Mus. ant. pract. $\mathrm{P}$ $985[7]$ The | Banquet of MUSICK; [...] | THE SECOND BOOK. [...].

Mus. ant. pract. C $835[2]$
COMES AMORIS; | OR THE COMpanion of LOVE. [...] 1688. - London, Thomas Moore for John Carr \& Samuel Scot, 1688.
John Blow, Pelham Humphrey, John Jackson, Mathew Locke, Henry Purcell, William Turner
S. Akeroyde, J. Banister, J.Blow, J. Hart, A. Marsh, D. Purcell, J. Roffey, Snow, Anonim
S. Akeroyde, Baptist, J. Blow, J. Hart, R. King, Marsh, F. Pigott, D. Purcell, H. Purcell, J. Roffey, Snow, Anonim

Sam. Akeroyde, J. Blow, R. Courtevile, A. Damascene, H. Hall, James Hart, P. Isaak, Robert King, Nicholson, D. Purcell, Henry Purcell, Reading, Sherbourne, M. Snow, Will. Turner, Anonim 
Harmonia Sacra; | OR: | DIVINE HYMNS | AND | DIALOGUES. | With A THOROW-BASS for the Theorbo-Lute, | Bass-Viol. Harpsichord, or Organ. | Composed by the Best MASTERS | The WORDS by several Learned and Pious Persons. | THE SECOND BOOK. | Angels and Mus. ant. Men' assisted by this Art, | May Sing together, pract. P though they Dwell apart. $\mid$ Mr. Waller of Divine Poesie. IMPRIMATUR, | Julii $1^{\circ}$. 1693. GUIL. $995[1]$

pract. $\mathrm{P}$

$995[3]$

Mus. ant.

pract. $\mathrm{P}$

$995[4]$
LANCASTER. I In the SAVOY: | Printed by

Edward Jones, for Henry Playford at his Shop near the Temple Church, | and at his HOUSE over-against the Blue-Ball in Arundel Street in the Strand: | Where also the First Book may be had. MDCXCIII. - London, Edward Jones for Henry Playford, 1693.
DELICIAE MUSICAE: | BEING, A | Collection of the newest and best SONGS | Sung at the Publick Theatres, most $\mid$ of them within the Compass of the FLUTE | WITH |A ThorowBass, for the Theorbo-Lute, |Bass-Viol, Harpsichord, or Organ. | Composed by several of the Best Masters. | THE FIRST BOOK. | LONDON, | April 23. 1695. D. Poplar. | Printed by J. Heptinstall, for Henry Playford, near the Temple Church, | or at his House over-against the Blew-Ball in Arundel-street: | Where also the New Catch-Book may be had. 1695. London, J. Haptinstall for Henry Playford, 1695.

DELICIAE MUSICAE [...] THE SECOND BOOK [...] London, J. Haptinstall for Henry Playford, 1695.
Barincloe, John Blow,

Giacomo Carissime, Jeremiah Clarke, Gratiani, Robert King, Daniel Purcell, Henry Purcell, Anonim
Blow, Courtiville, Henry Purcell
John Gilbert, Henry Hall, Henry Purcell
Mus. ant. pract. $\mathrm{P}$ $995[5]$
DELICIAE MUSICAE [...] THE THIRD BOOK [...] Where also the First and Second | Bookmay be had. The Fourth Book will be Publish'd next Term, which will I make the First Volume Compleat. MDCXCVI - London, J. Haptinstall for Henry Playford, 1696.
John Eccles, John Greeman, Henry Purcell, Anonim
DELICIAE MUSICAE [...] THE FOURTH BOOK [...] and Sold by him at his Shopin the Temple-Change Fleetstreet. The Four Books,

Mus. ant. pract. $\mathrm{P}$ 995 [6] with 3 Elegies on our Late | Gracious Queen Mary, Sett by Dr. Blow, and the Late Famous Mr. Henry Purcell, | Compleats the First Volume. The Second Book of the Second Volume will be Pub-lish'e next Term. 1696. | Price One Shilling. - London, J. Haptinstall for Henry Playford, 1696. 


\begin{tabular}{|c|c|c|}
\hline Sygnatura & Karta tytułowa & Kompozytorzy \\
\hline $\begin{array}{l}\text { Mus. ant. } \\
\text { pract. P } \\
995[2]\end{array}$ & $\begin{array}{c}\text { Two DIVINE | HYMNS: | BEING A | } \\
\text { SUPLIMENT | To the Second BOOK of | } \\
\text { HarmoniaeSacrae. | LONDON: | Printed by W. } \\
\text { Pearson, in Red-Cross-Alley in Jewin Street, | } \\
\text { for Henry Playford, at his Shop in the Temple- } \\
\text { Change | Fleet Street. Price 6d. Or Stitch'd up } \\
\text { with the Second | Book of Harmonia Sacra, } 4 \\
\text { s. 1700. - London, Wiliam Pearson for Henry } \\
\text { Playford, } 1700 .\end{array}$ & Jer. Clerk, Wiliam Croft \\
\hline $\begin{array}{l}\text { Mus. ant. } \\
\text { pract. M } \\
400[4]\end{array}$ & $\begin{array}{l}\text { A collection of the English songs for one voice, a } \\
\text { flute and a thorough bass. }\end{array}$ & $\begin{array}{l}\text { John Barnett, Jeremiah } \\
\text { Clarke, Courtevill, John } \\
\text { Eccles, Leveridge, Dan. } \\
\text { Purcell, Henry Purcell }\end{array}$ \\
\hline
\end{tabular}

Tabela 1. Angielskie antologie wokalne w kolekcji tzw. Berlinki (zachowano pisownię oryginalną) ${ }^{47}$

\section{Bibliografia}

Barnard J., London Publishing, 1640-166o. Crisis, Continuity, and Innovation, „Book History” 2001, t. 4, nr 1.

Blagden C., The Stationers' Company. A History, 1403-1959, Stanford University 1977.

Bukofzer M.F., Music in the Baroque Era. From Monteverdi to Bach, New York 1947.

Dean-Smith M., English Tunes Common to Playford's Dancing Master, the Keyboard Books and Traditional Songs and Dances. Preceded by Some New Findings Concerning the Life and Career of John Playford, "Proceedings of the Royal Musical Association” 1957, t. 79.

Dean-Smith M., Temperley N., Playford, [w:] The New Grove of Music and Musicians, red. D. Root i in., [online] http://www.oxfordmusiconline.com/public/book/omo_gmo [dostęp: 8.04.2016].

47 Opracowano na podstawie: A. Patalas, Katalog starodruków muzycznych ze zbiorów byłej Pruskiej Biblioteki Państwowej w Berlinie, przechowywanych w Bibliotece Jagiellońskiej w Krakowie, Kraków 1999, s. 1660-1689. 
Eskew H., Hymn, § IV: Protestant, [w:] The New Grove of Music and Musicians, red. D. Root i in., [online] http://www.oxfordmusiconline. com/public/book/omo_gmo [dostęp: 8.04.2016].

Fortune N., Greer D., Dill Ch., Air, [w:] The New Grove of Music and Musicians, red. D. Root i in., [online] http://www.oxfordmusiconline. com/public/book/omo_gmo [dostęp: 8.04.2016].

Franklin D., Turner William, [w:] The New Grove of Music and Musicians, red. D. Root i in., [online] http://www.oxfordmusiconline. com/public/book/omo_gmo [dostęp: 8.04.2016].

Global copyright. Three hundred years since the Statute of Anne, from 1709 to cyberspace, red. L. Bentlyi in., Cheltenham 2010.

Herissone R., Musical Creativity in Restoration England, Cambridge University, 2013.

Herissone R., Playford, Purcell, and the Functions of Music Publishing in Restoration England, „Journal of the American Musicological Society" 2010, t. 63, nr 2.

Holman P., Farmer Thomas, [w:] The New Grove of Music and Musicians, red. D. Root i in., [online] http://www.oxfordmusiconline. com/public/book/omo_gmo [dostęp: 8.04.2016].

Holman P., King Robert, [w:] The New Grove of Music and Musicians, red. D. Root i in., [online] http://www.oxfordmusiconline.com/ public/book/omo_gmo [dostęp: 8.04.2016].

Holman P., Locke Matthew, [w:] The New Grove of Music and Musicians, red. D. Root i in., [online] http://www.oxfordmusiconline. com/public/book/omo_gmo [dostęp: 8.04.2016].

Humphreys M., Daniel Purcell, [online] http://www.danielpurcell. bemused.org.uk/ [dostęp: 5.03.2016].

Jeans S., John Reading, [w:] The New Grove of Music and Musicians, red. D. Root i in., [online] http://www.oxfordmusiconline.com/ public/book/omo_gmo [dostęp: 8.04.2016].

Jenkinson M., Culture and Politics at the Court of Charles II, 1660-1685, Suffolk 2010.

Jones A.V., Carissimi Giacomo, [w:] The New Grove of Music and Musicians, red. D. Root i in., [online] http://www.oxfordmusiconline. com/public/book/omo_gmo [dostęp: 8.04.2016].

Keller R.M., The Dancing Master, 1651-1728. An Illustrated Compendium, Country Dance and Songs Society Inc. 200o, [online] http://www. izaak.unh.edu/nhltmd/indexes/dancingmaster/ [dostęp: 10.03.2016]. 
Kidston F., John Playford, and 17th-Century Music Publishing, „The Musical Quarterly" 1918, t. 4, nr 4.

Kidston F., The Petition of Mrs Eleanor Playford, „The Library” 1916, t. VII. Laurie M., Lincoln S., John Eccles, [w:] The New Grove of Music and Musicians, red. D. Root i in., [online] http://www.oxfordmusiconline. com/public/book/omo_gmo [dostęp: 8.04.2016].

Lindenbaum P., John Playford: Music and politics in the interregnum, „Huntington Library Quarterly” 2001, t.64, nr 1/2.

Miller M., Carr John, [w:] The New Grove of Music and Musicians, red. D. Root $\mathrm{i}$ in., [online] http://www.oxfordmusiconline.com/public/ book/omo_gmo [dostęp: 8.04.2016].

Parliament, [w:] Encyclopedia Britannica, [online] http://global.britannica.com/topic/Parliament\#toc215007 [dostęp: 10.05.2016].

Patalas A., Katalog starodruków muzycznych ze zbiorów byłej Pruskiej Biblioteki Państwowej w Berlinie, przechowywanych w Bibliotece Jagiellońskiej w Krakowie, Kraków 1999.

Shaw W., Beeks, G., Croft William, [w:] The New Grove of Music and Musicians, red. D. Root i in., [online] http://www.oxfordmusiconline. com/public/book/omo_gmo [dostęp: 8.04.2016].

Shaw W., Powell Ch., Johnstone H.D., Clarke Jeremiah, [w:] The New Grove of Music and Musicians, red. D. Root i in., [online] http://www. oxfordmusiconline.com/public/book/omo_gmo [dostęp: 8.04.2016].

Smith W.C., Playford: some hitherto unnoticed catalogues of early Music, „The Musical Times” 1926, t. 67, nr 1001.

Spink I., Akeroyde Samuel, [w:] The New Grove of Music and Musicians, red. D. Root i in., [online] http://www.oxfordmusiconline.com/ public/book/omo_gmo [dostęp: 8.04.2016].

Spink I., Courteville Raphael, [w:] The New Grove of Music and Musicians, red. D. Root i in., [online] http://www.oxfordmusiconline. com/public/book/omo_gmo [dostęp: 8.04.2016].

Spink I., Damascene Alexander, [w:] The New Grove of Music and Musicians, red. D. Root i in., [online] http://www.oxfordmusiconline. com/public/book/omo_gmo [dostęp: 8.04.2016].

Spink I., English seventeenth-century dialogues, „Music \& Letters” 1957, t. 38, nr 2.

Spink I., Hart James, [w:] The New Grove of Music and Musicians, red. D. Root $\mathrm{i}$ in., [online] http://www.oxfordmusiconline.com/public/ book/omo_gmo [dostęp: 8.04.2016]. 
Spink I., Johnson Robert, [w:] The New Grove of Music and Musicians, red. D. Root i in., [online] http://www.oxfordmusiconline.com/ public/book/omo_gmo [dostęp: 8.04.2016].

Spink I., Marsh Alfonso, [w:] The New Grove of Music and Musicians, red. D. Root i in., [online] http://www.oxfordmusiconline.com/ public/book/omo_gmo [dostęp: 8.04.2016].

Spink I., Snow Moses, [w:] The New Grove of Music and Musicians, red. D. Root $\mathrm{i}$ in., [online] http://www.oxfordmusiconline.com/public/ book/omo_gmo [dostęp: 8.04.2016].

Temperley N., John Playford and the metrical psalms, „Journal of the American Musicological Society" 1972, t. 25, nr 3.

Temperley N., John Playford and the Stationers' Company, „Music \& Letters" 1973, t. 54, $\mathrm{nr} 2$.

That Second Bottle. Essays on the Earl of Rochester, red. N. Fisher, Manchester University Press 2000.

Whitlock K., John Playford's the English Dancing Master 1650/51 as Cultural Politics, „Folk Music Journal” 1999.

Wood B., Blow John, [w:] The New Grove of Music and Musicians, red. D. Root $\mathrm{i}$ in., [online] http://www.oxfordmusiconline.com/public/ book/omo_gmo [dostęp: 8.04.2016].

Wood B., Humphrey Pelham, [w:] The New Grove of Music and Musicians, red. D. Root i in., [online] http://www.oxfordmusiconline. com/public/book/omo_gmo [dostęp: 8.04.2016].

\section{Abstract}

“Angels and Men' assisted by this Art, May Sing together, though they Dwell apart" - early English prints of court ayres and sacred songs from the second half of the seventeenth century kept in the Jagiellonian Library

The article describes the group of seventeen early English prints from the second half of the $17^{\text {th }}$ century. The prints are part of the collection of the former Preußische Staatsbibliothek in Berlin kept in The Jagiellonian University and contain ayres and religious songs. Fourteen of them were published by John and Henry Playford. The first part of the paper shows the biographies of the publishers and 
brings the state of research on their work. The second part includes the detailed description of the seventeen of early English prints. The final part presents the content of the prints and biographies of its most important composers.

Keywords: John Playford, Henry Playford, ayre 